KS. ROBERT KaCZMAREK

KaTOWICE

\title{
ELEMENTY ORGANIZACYJNE KATECHEZY PRZYGOTOWUJĄCEJ MLODZIEŻ DO SAKRAMENTU BIERZMOWANIA W POLSCE I W NIEMCZECH
}

Od powrotu katechezy do szkół poprzez przywrócenie szkolnego nauczania religii w 1990 roku, które było skutkiem przemian społeczno-politycznych roku 1989, minęło ćwierć wieku. W tym czasie polskie społeczeństwie doznało wielu przeobrażeń, dotyczących m.in. jego religijności oraz relacji do Kościoła. Religijna socjalizacja nie jest już dzisiaj w wielu sytuacjach oczywistością, a stosunek młodzieży do Kościoła jest często obojętny. Łatwo dostrzec również zmiany jej mentalności pod wpływem laickich i konsumpcyjnych wpływów. Coraz częściej obserwuje się religijny analfabetyzm młodzieży, który jest konsekwencją „życia na pozór” oraz braków na płaszczyźnie intelektualnej i przeżyciowej, dotyczących sfery wiary ${ }^{1}$. Większość młodzieży znikła z parafii i nie czuje większego związku ze wspólnotą, a pojawia się w niej tylko okazjonalnie, zwłaszcza przy okazji przygotowania do bierzmowania. W takie sytuacji staje się ono niezwykłą szansą na pozyskanie młodzieży, a Katechizm Kościoła Katolickiego stawia przed nim następujące cele: doprowadzić chrześcijanina „do głębszego zjednoczenia z Chrystusem, do większej zażyłości z Duchem Świętym, Jego działaniem, darami i natchnieniami, aby mógł lepiej podjąć apostolską odpowiedzialność życia chrześcijańskiego” oraz „obudzić zmysł przynależności do Kościoła Jezusa Chrystusa” (por. KKK 1309). Jak to osiągnąć w zmieniających się warunkach życia współczesnych czasów? Katecheza związana z bierzmowaniem napotyka na trudności, które jeszcze jakiś czas temu były nieznane, a dzisiaj ewoluują w szybkim tempie. Osoby odpowiedzialne za przygotowanie młodzieży do bierzmowania oraz szafarze tego sakramentu stwierdzają w rozmowach, że trudności dotyczą już nie tylko spraw koncepcji przygotowania, jego zorganizowania czy brakiem jednolitej struktury w sąsiadujących ze sobą parafiach, albo z niespełnianiem przez młodzież wymagań, ale coraz częściej z tym, że wzrasta liczba osób, które nie chcą przystępować do tego sakramentu. Obserwuje się to szczególnie w dużych miastach. Poza tym niepokojący jest fakt, że młodzież często kończy swój kontakt z Kościołem oraz religijne praktyki po

1 Por. R. Chałupniak, Religijny analfabetyzm młodzieży, Kat 7-8 (2013), s. 85. 
przyjęciu bierzmowania. To wszystko skłania do poszukiwania nowych inspiracji dla wypracowywania modelu katechezy do bierzmowania, który skutkowałby rozbudzeniem lub pogłębieniem wiary młodzieży i jej pozostaniem w Kościele².

\section{Poszukiwania optymalnego kształtu katechezy do bierzmowania}

W Polsce ciągle poszukuje się odpowiedzi na pytania o optymalny kształt katechezy przygotowującej do sakramentu bierzmowania. Ks. Paweł Mąkosa zwraca uwagę na konieczność preewangelizacji w formacji chrześcijańskiej, która miałaby uwrażliwić człowieka na wartości religijne oraz ukazać wiarygodność chrześcijaństwa i Kościoła katolickiego, żeby być gotowym na przyjęcie Dobrej Nowiny ${ }^{3}$. Ks. Tadeusz Panuś z kolei zauważa, że przygotowanie do bierzmowania nie może być kolejną lekcją religii, tyle że w parafii. Jego zdaniem celem spotkań przed bierzmowaniem powinna być refleksja kandydata nad własną wiarą oraz wiarą Kościoła oraz budzenie głodu za Panem Bogiem, a nie tylko przekonywanie się, czy młodzież zna wyznaczone definicje katechizmowe. W katechezie przygotowującej do bierzmowania musi być coś z fenomenu Lednicy czy spotkań modlitewnych Taize ${ }^{4}$ Ś śwatowe Dni Młodzieży mogą również odegrać swoją rolę, jeśli tylko weźmie się je pod uwagę w przygotowaniu do bierzmowania. Fenomen spotkań, zainicjowanych przez św. Jana Pawła II wynika z tego, że młodemu człowiekowi potrzebne jest doświadczenie wspólnoty wiary przeżywanej wśród rówieśników. Dzięki temu zauważa on, że na drodze wiary nie jest sam, ale są również inni, którzy budują swoje życie na tych samych wartościach. Łatwiej jest wtedy trwać w wierze lub ją odkrywać. Nie bez znaczenia jest również obecna w młodzieży potrzeba przeżywania tego typu spotkań jako formy partycypacji w czymś niecodziennym i emocjonalnego zaangażowania. Często rodzi się w nich potrzeba osobistego spotkania Chrystusa i pójścia Jego drogą. Światowe Dni Młodzieży stwarzają ku temu szczególną okazję zarówno na etapie przygotowania do bierzmowania, jak i po jego przyjęciu. Zaproponowanie kandydatom do bierzmowania i osobom po bierzmowaniu takiej formy zaangażowania i przeżywania może przyczynić się do nowego spojrzenia przez nich na dar wiary i konieczność jego nieustannego rozwoju, jak i na wspólnotę Kościoła.

\footnotetext{
2 Por. R. Kaczmarek, Model katechezy przygotowujacej do sakramentu bierzmowania w Polsce i w Niemczech, Kraków 2014, s. 14n.

3 Por. P. Mąkosa, Preewangelizacja pierwszym i koniecznym etapem formacji chrześsijańskiej, Kat 7-8 (2010), s. 26.

4 Por. T. Panuś, Nowe możliwości intensyfikacji posługi katechetycznej w Polsce, Kat 12 (2004), s. 13.
} 


\section{Korzystanie ze wzajemnych doświadczeń}

Zastanawiając się nad optymalnym kształtem katechezy do bierzmowania warto również skorzystać z doświadczeń innych, którzy już wcześniej poszukiwali nowych rozwiązań jako odpowiedź na nową sytuację młodych ludzi. Jako przykład może posłużyć Kościół w Niemczech, który przed wielu laty musiał stawić czoła wyzwaniom współczesności, związanym z zanikiem tradycyjnych form religijności oraz religijnej socjalizacji. Konsekwencją tego był dystans wielu ludzi do wiary i Kościoła oraz bardzo różny, niejednokrotnie prekatechumenalny, poziomie rozwoju ich wiary. W duszpasterstwie sakramentalnym zaczęto więc poszukiwać nowych sposobów dotarcia do młodzieży i wprowadzenia ich w życie Kościoła. Rezultatem było wypracowanie adekwatnych metod i form pracy z młodymi ludźmi w ramach przygotowania do bierzmowania. Kościół w Polsce może więc skorzystać z niemieckich doświadczeń katechezy do bierzmowania, zaś Kościół niemiecki z polskich inspiracji, co w kontekście zbliżających się Światowych Dni Młodzieży w Krakowie w 2016 r. stanowi szczególną wartość.

Analizując, na podstawie przeprowadzonych ankiet ${ }^{5}$, praktykę katechezy do bierzmowania w Polsce i w Niemczech weźmiemy tutaj pod uwagę jedynie jej elementy organizacyjne: miejsce, w którym się odbywa; wiek katechizowanych; ramy czasowe; ogólny przebieg i rodzaje katechetycznych spotkań. Intersujące są jednak również pozostałe zagadnienia, takie jak podstawowe założenia katechezy do bierzmowania, czy jej elementy treściowo-metodyczne.

\section{Parafia jako uprzywilejowane miejsce katechezy do bierzmowania oraz wrażliwość na nowe miejsca katechetyczne}

Matthias Sellmann zebrał owoce teologicznej debaty na temat parafii oraz jej praktycznych modeli w Niemczech, opatrując je prowokacyjnym tytułem: „Parafia bez przyszłości?”. Stwierdza, że troska o to, co będzie dalej z parafią, może być uważana jako jedno z najbardziej nurtujących zagadnień w niemieckim katolicyzmie $^{6}$. Interesująco brzmi w tym kontekście spostrzeżenie ks. Tadeusz Panusia,

5 Autor przeprowadził badanie sondażowe ankiety z zastosowaniem techniki ankiety na potrzeby pracy doktorskiej: Model katechezy przygotowujacej do sakramentu bierzmowania w Polsce i w Niemczech, przygotowanej pod kierunkiem ks. prof. Tadeusza Panusia na Uniwersytecie Papieskim Jana Pawła II w Krakowie. Kwestionariusz ankiety wraz z instrukcją rozesłano do osób odpowiedzialnych w poszczególnych 41 polskich i 27 niemieckich diecezjach za katechezę przygotowująca do sakramentu bierzmowania, a więc do Dyrektorów Wydziałów Katechetycznych lub Duszpasterskich, którzy w razie konieczności przekazywali je dalej. Zbieranie danych empirycznych rozpoczęto w sierpniu 2012 roku, a zakończono w kwietniu 2013 roku.

6 Por. M. Sellmann, Gemeinde ohne Zukunft? Theologische Debatte und praktische Modelle, Freiburg im Breisgau 2013, s. 9. 
że katecheza do bierzmowania „stwarza szansę dowartościowania i przywrócenia znaczenia parafii w ramach każdego Kościoła lokalnego"7.

$\mathrm{W}$ ankietach, przeprowadzonych zarówno w polskich, jak i w niemieckich diecezjach na pytanie: gdzie odbywa się katecheza do bierzmowania, udzielono odpowiedzi - w parafii zamieszkania kandydata. Korzysta z tego parafia, gdyż dzięki katechezie do bierzmowania gromadzi się przy niej młodziė̇, a po bierzmowaniu część pozostaje przy parafii. Niemniej jednak parafia powinna zatroszczyć się o pozyskanie młodzieży dla katechezy, odbywającej się w jej przestrzeni oraz ukazywać kandydatom konkretne możliwości współdziałania i zaangażowania. Nie dokona się to, jeśli parafia nie będzie domem otwartym, gościnnym i zapraszającym młodych ludzi. Wiele razy w rozmowach z młodzieżą okazywało się, że często nie doświadczali wyrozumiałości czy to ze strony duszpasterzy czy członków wspólnoty parafialnej.

Pomimo podstawowej zasady organizowania katechezy do bierzmowania w parafii zamieszkania kandydata, pomiędzy polską a niemiecką rzeczywistością istnieje kilka różnic. W Polsce od tej zasady odchodzi się tylko w wyjątkowych przypadkach (za zgodą proboszcza parafii zamieszkania kandydata). W Niemczech zaś jest możliwe, żeby kandydat uczestniczył w katechezie do bierzmowania w parafii, na terenie której znajduje się szkoła lub tam gdzie mieszka przyjaciel czy przyjaciółka. W specyficznej sytuacji niemieckiego Kościoła, w związku z praktyką łączenia parafii katecheza odbywa się nieraz na poziomie jednostek duszpasterskich czy nawet dekanatów. Może ona jednak mieć również miejsce w tzw. „Jugendkirchen”, czyli kościołach młodzieżowych, centrach duszpasterstwa młodzieży, szkołach arcybiskupich, katolickich wspólnotach szkół wyższych lub katolickich związkach młodzieżowych. Oznacza to, że w Niemczech bierze się pod uwagę charakterystyczną dla współczesnych czasów mobilność ludzi, która wymusza elastyczne podejście do młodych w kontekście przygotowania do bierzmowania. W związku z zanikającą w społeczeństwie religijną socjalizacją w Niemczech mocno podkreśla się również konieczność możliwie szerokiego połączenia przygotowania do bierzmowania z różnymi miejscami autentycznego życia wiarą w Kościele - chodzi o kościelne instytucje charytatywne, realizujące w praktyce przykazanie miłości; o katolickie związki i stowarzyszenia, gromadzące młodzież w stabilnych grupach społecznych, dających poczucie bycia w domu oraz możliwość stworzenia zażyłych relacji między sobą; chodzi również o klasztory, miejsca pielgrzymkowe, domy formacyjne, ale również nietypowe miejsca (takie jak miejsca pamięci czy szczególne miejsca na łonie natury). Nie pomija się również kina, przestrzeni kultury i muzyki oraz wymiaru ekumenicznego. W Polsce prawie wcale nie ma mowy o takich miejscach, $\mathrm{z}$ wyjątkiem młodzieżowych grup formacyjnych w parafii oraz czasami form

\footnotetext{
T. Panuś, Duszpasterstwo katechetyczne w parafii dla młodzieży przygotowującej się do przyjęcia bierzmowania, w: Abyśmy podtrzymywali nadzieję. Księga jubileuszowa ku czci ks. Prof. Romana Murawskiego SDB, red. P. Tomasik, Warszawa 2005, s. 259.
} 
posługi charytatywnej. Podkreśla się jedynie konieczność powiązania katechezy do bierzmowania $\mathrm{z}$ domem rodzinnym i szkołą, ale to również jest obecne w niemieckiej praktyce. Dowodzi to, że Kościół niemiecki poszukuje różnych miejsc, w których młodzi ludzie mogliby przekonać się, że wiara kształtuje w realny sposób życie pewnych grup ludzi i że należy do codzienności, a nie jest tylko odświętnym zwyczajem, wynikającym z przejętej tradycji. Poza tym nie do pomyślenia jest wiara bez wspólnoty i nie można jej bez niej przeżywać.

W związku z powyższym można wyciągnąć wniosek, że wartością polskiej praktyki jest więź katechezy do bierzmowania z parafią, w której mieszka kandydat. Biorąc jednakże pod uwagę niemiecką praktykę wychodzenia również poza parafię zamieszkania kandydata ze względu na mobilność ludzi i inne przesłanki oraz fakt, że w przyszłości stanie się tak w Polsce, wydaje się, że od Kościoła w Niemczech można nauczyć się większej wyrozumiałości, otwartości i przychylności dla młodzieży, która zwraca się z prośbą o zgodę na przygotowanie w innej parafii, a przede wszystkim - podjęcia spokojnego dialogu na ten temat. Bardzo często bowiem brak wyrozumiałości dla argumentów kandydata i jego rodziców, będących niejednokrotnie w luźnym związku z lokalną wspólnotą, prowadzi do jeszcze większego oddalenia ich od Kościoła ${ }^{8}$. W niektórych przypadkach konieczne jest szersze spojrzenie na Kościół niż tylko przez pryzmat własnej wspólnoty parafialnej. Najważniejsze jest bowiem, aby młody człowiek odnalazł jakiekolwiek miejsce w Kościele, gdzie będzie mógł dzielić się i świętować swoją wiarę. Duszpasterze powinni mieć otwarte oczy i odkrywać miejsca i czas, w których skondensowana jest chrześcijańska wiara, a tym samym wykorzystać je jako możliwe miejsca katechezy. Począwszy od parafii a skończywszy nawet na formach kościelnego streetworkingu pod warunkiem, że osoby które darzy się szczególnym zaufaniem będą przez dłuższy czas dostępne i będzie można z nimi rozmawiać9.

\section{Wiek czy gotowość kandydata warunkiem koniecznym do przyjęcia bierzmowania?}

Zagadnienie wieku do bierzmowania jest ciągle obecne w refleksji teologicznej o sakramencie bierzmowania, a poglądy na ten temat są bardzo zróżnicowane ${ }^{10}$. Porównując wyniki ankiet w Polsce i w Niemczech, możemy stwierdzić, że wiek bierzmowania w Polsce jest bardziej jednolity niż w Niemczech. Zgodnie z postanowieniami II Polskiego Synodu Plenarnego (1991-1999) sakrament bierzmowania

\footnotetext{
8 Por. R. Kaczmarek, Model katechezy, dz. cyt., s. 483n.

9 Por. P. C. Höring, Konzeptionslinien der Firmkatechese, w: Handbuch der Katechese, A. Kaupp,

S. Leimgruber, M. Scheidler (Hg.), Freiburg im Breisgau 2011, s. 430.

10 Por. A. Skowronek, Odnowa charyzmatyczna $w$ świetle nurtów charyzmatycznych $w$ Kościele, Roczniki Teologiczne 6 (1996), s. 79n.
} 
powinien być udzielany młodzieży III klas gimnazjalnych, a więc w wieku 15-16 lat (por. PSL 112). Taki model przyjęto $\mathrm{w}$ większości polskich diecezji, chociaż $\mathrm{w}$ nielicznych bierzmowania udziela się uczniom I klas ponadgimnazjalnych, czyli 16-17-latkom ${ }^{11}$. Pozostałe rozwiązania są sporadyczne i związane najczęściej z tym, że bierzmowanie jest udzielane w parafii co kilka lat. W Niemczech Synod z Würzburga (1971-1975) ustalił dolną granicę wieku bierzmowania na około 12 rok życia ${ }^{12}$. Poszczególnym diecezjom dano jednak możliwość podejmowania w tym względzie innych decyzji, co sprawiło że rozpiętość wiekowa przyjmujących regularnie sakrament bierzmowania waha się od 11 do 18 lat. Najczęściej udziela się go jednak w wieku 14-16 lat. Duża rozpiętość wieku w Niemczech wiąże się tam nie tylko $\mathrm{z}$ tym, że $\mathrm{w}$ wielu wiejskich parafiach ogólnie przyjmuje się niższy wiek do bierzmowania niż w mieście oraz nie udziela się go co roku, ale również $\mathrm{z}$ tym, że wielu młodych ludzi z różnych względów nie przystępuje do bierzmowania wraz z grupą rocznikową. Okazuje się również, że wiek do bierzmowania w Niemczech uwarunkowany jest nie tylko czynnikami szkolnymi, społecznymi czy związanymi z rozwojem i dojrzewaniem młodego człowieka, lecz również $\mathrm{z}$ wizją duszpasterstwa młodzieży w parafii. Tam, gdzie katechezę do bierzmowania traktuje się jako część działań duszpasterstwa młodzieży oraz stawia się na dobrowolną decyzję związaną z cywilną pełnoletniością, przesuwa się wiek bierzmowania na $16-18$ lat $^{13}$.

Dla polskiej praktyki dotyczącej wieku katechezy i przyjęcia sakramentu bierzmowania mogą być cenne dwa stwierdzenia z dokumentu Episkopatu Niemiec na temat praktyki duszpasterstwa sakramentalnego Sakramentenpastoral im Wandel. Pierwsze związane jest z tym, że decyzja o wieku przyjęcia bierzmowania powinna uwzględniać związek pomiędzy pełnym przyjęciem własnego chrztu oraz doświadczeniem życia we wspólnocie wiary. Drugie zaś przypomina, że ważniejsze od wieku bierzmowania jest dobre przygotowanie katechetyczne oraz wprowadzenie w życie parafii, zaś po przyjęciu ciągłe odnawianie tego sakramentu ${ }^{14}$. Patrick Höring stwierdza, że w przyszłości nie można już udzielać bierzmowania wtedy, kiedy przyjedzie biskup, ale wtedy, gdy dana osoba będzie gotowa odnowić swoje wyznanie wiary i podjąć swoje posłannictwo. Oznacza to odwrót od principium

\footnotetext{
11 Rozwiązanie takie przyjęły diecezje: Częstochowa, Elbląg, Koszalin-Kołobrzeg, Legnica, Warszawa, Warszawa-Praga, Zielona Góra-Gorzów. Dodać należy również diecezje: Kraków i Łowicz, gdzie bierzmuje się młodzież klas III gimnazjum lub I ponadgimnazjalnej, Gniezno, gdzie czasami bierzmowania udziela się w klasach I-III szkoły ponadgimnazjalnej, i Przemyśl, gdzie bierzmuje się w III gimnazjalnej, a niekiedy w I ponadgimnazjalnej.

12 Por. Würzburger Synode, Schwerpunkte heutiger Sakramentenpastoral 3.4.1, s. 256.

13 Por. „Geistblitz und Tatendrang“. Firmpastoral neu denken, Erzbistum Köln. Abteilung Jugendseelsorge, M. Kolb (Hg.), Köln 2011, s. 4; R. Kaczmarek, Model katechezy, dz. cyt., s. 483n.

14 Por. Die deutschen Bischöfe - Pastoral-Kommission, Sakramentenpastoral im Wandel. Überlegungen zur gegenwärtigen Praxis der Feier der Sakramente - am Beispiel von Taufe, Erstkommunion und Firmung, Bonn 19963, s. 49.
} 
rocznikowego doświadczenia pastoralnego i rocznikowego udzielania bierzmowania na rzecz bardziej zindywidualizowanego. Katecheza do bierzmowania będzie musiała bardziej niż do tej pory mieć wzgląd na swoich adresatów ${ }^{15}$.

\section{Ramy czasowe katechezy do bierzmowania}

Kolejnym elementem organizacyjnym modeli katechezy przygotowującej do bierzmowania w Polsce i w Niemczech jest zagadnienie jej ram czasowych. Wyniki ankiet świadczą o dużej rozbieżności pomiędzy praktyką w Polsce i w Niemczech w tym względzie. W Polsce bowiem przygotowanie do bierzmowania trwa przynajmniej rok, dwa lub trzy lata, w Niemczech natomiast praktykuje się przynajmniej trzymiesięczne przygotowanie do bierzmowania, które często trwa pół roku, a w niektórych przypadkach rozciąga się na rok, lecz bardzo rzadko na dwa lata. Poszukując odpowiedzi na pytanie, dlaczego istnieje taka różnica długości przygotowania do bierzmowania, można dojść do wniosku, że w Polsce obserwowane wydłużanie czasu przygotowania ma być lekarstwem na niedojrzałość kandydatów. Rozciągnięte w czasie przygotowanie skutkuje pozytywnie w wielu młodych na płaszczyźnie pogłębienia ich relacji z Bogiem oraz kształtowania postaw wiary, a równocześnie jest to sposób na dłuższe związanie młodzieży z parafią. Pozytywne owoce dostrzegają biskupi udzielający bierzmowania - młodzież po trzyletnim przygotowaniu głębiej uczestniczy w liturgii bierzmowania, niż ta która przygotowywała się krótko. Nauczyciele i katecheci uczący w szkołach ponadgimnazjalnych uważają ją często za „lepszą, rozpoznawalną i pozytywnie rzucającą się w oczy”16. Otwartym pozostaje jednak pytanie na ile postawy te mają charakter trwały, szczególnie jeśli chodzi o praktyki religijne, dalszą obecność w parafii oraz życiowe postawy po przyjęciu bierzmowania. W Niemczech na czas przygotowania do bierzmowania wpływ ma przede wszystkim forma przygotowania: spotkania weekendowe i całodniowe zajęcia skutkują krótszym czasem przygotowania, zaś spotkania w regularnych grupach - dłuższym. Poza tym znaczenie ma również zróżnicowana możliwość wyboru zajęć w ramach kursu do bierzmowania. W polskim modelu o długości przygotowania decydują bardziej racje duszpastersko-teologiczne, zaś w niemieckim - racje organizacyjno-koncepcyjne katechezy. Biorąc pod uwagę ten element modelu przygotowania można obustronnie skorzystać z doświadczeń: Kościół niemiecki może odwołać się do doświadczeń polskich, z których wynika, że przygotowanie przez dłuższy czas przy parafii tworzy trwalsze więzy młodzieży pomiędzy sobą i z parafią, pogłębia młodych w wierze oraz przyczynia się, że zarówno

\footnotetext{
15 Por. P. C. Höring, Konzeptionslinien der Firmkatechese, dz. cyt., s. 428.

16 Por. T. Panuś, Parafia uprzywilejowanym miejscem dla katechezy przygotowującej do sakramentu dojrzałości chrześcijańskiej. Doświadczenia krakowskie, w: Dzisiejszy bierzmowany. Problemy i wyzwania, red. J. Stala, Kielce 2005, s. 262.
} 
szafarze bierzmowania, jak i środowisko szkolne widzi w nich wartościową grupę. Katecheza spełnia więc swoją funkcję inicjacyjno-wychowawczą. Kościół w Polsce zaś może wykorzystać w uzasadnionych przypadkach bardziej „skondensowaną” formę przygotowania, która ze względu na krótszy czas trwania kursu jest bardziej zachęcająca dla części młodzieży. Uwzględnia poza tym warunki organizacji życia współczesnej młodzieży i ich rodzin ${ }^{17}$.

\section{Ramowy przebieg przygotowania do bierzmowania}

W obszarze badań nad modelem organizacyjnym katechezy do sakramentu bierzmowania w Polsce i w Niemczech znajduje się również kwestia ramowego przebiegu przygotowania do bierzmowania. Różnice w długości trwania przygotowania nie wykluczają elementów wspólnych dla poszczególnych rozwiązań. W polskiej praktyce zasadniczo mówi się o trzech etapach przygotowania: dalszym (katechizacja w szkole podstawowej); bliższym (lata nauki w gimnazjum) oraz bezpośrednim (ostatni rok nauki w gimnazjum) ${ }^{18}$. W niektórych diecezjach przyporządkowano do nich dodatkowe określenia ${ }^{19}$. W Niemczech nie spotyka się takiego podziału i przygotowanie ogranicza się zasadniczo do etapu bezpośredniego. Dzięki obowiązującym w każdej polskiej diecezji instrukcjom i wskazaniom biskupów czy Wydziałów Katechetycznych, łatwiej jest wydobyć elementy ramowego przygotowania. Obejmuje ono wyznaczone formy spotkań (w małych grupach, celebracje, nabożeństwa okresowe), czas ich realizacji (konkretne miesiące) oraz różne działania kandydatów do bierzmowania. Zalicza się do nich przykładowo: złożenie przez kandydata pisemnej deklaracji uczestnictwa w formacji lub zgłoszenie przez rodziców dziecka do przyjęcia bierzmowania (na początku przygotowania); złożenie na ręce proboszcza prośby do biskupa o udzielenie tego sakramentu wraz z motywacją jego przyjęcia; egzamin (w różnej formie); rozmowa; obrzęd dopuszczenia do

\footnotetext{
17 Por. R. Kaczmarek, Model katechezy, dz. cyt., s. 486.

18 Por. B. Klaus, Aspekt pastoralno-katechetyczny przygotowania do bierzmowania, Currenda 2 (1988), s. 227-234; H. Sobeczko, Sakrament bierzmowania w duszpasterstwie, Ruch Biblijny i Liturgiczny 1-2 (1975), s. 56-58.

19 W archidiecezji białostockiej ramach przygotowania trzyletniego poszczególne jego etapy zostały wyodrębnione i nazwane: formacja wstępna, pogłębienie formacji, bezpośrednie przygotowanie do sakramentu bierzmowania. Zob. Instrukcja duszpastersko-katechetyczna Wydziału Katechetycznego dotyczaca przygotowania i udzielania sakramentu bierzmowania $\mathrm{z}$ dnia 31. sierpnia $2005 \mathrm{r}$. W instrukcji diecezji szczecińsko-kamieńskiej spotykamy nazwy: etap ewangelizacyjny, etap katechizacyjny, etap mistagogiczny. Zob. Instrukcja duszpastersko-katechetycznego przygotowania młodzieży szkolnej do sakramentu bierzmowania w archidiecezji szczecińsko-kamieńskiej z 31. grudnia $2000 \mathrm{r}$. $\mathrm{W}$ archidiecezji częstochowskiej wyodrębniono etap wstępnego przygotowania (I rok) i przygotowane właściwe (II rok). Zob. Wskazania duszpasterskie przygotowaniu kandydatów do sakramentu bierzmowania na terenie Archidiecezji Częstochowskiej z dnia 02. grudnia 1996 r.
} 
przyjęcia sakramentu bierzmowania; przyjęcie przez kandydatów różnych symboli wiary. Niektóre z wymienionych elementów występują również w niemieckiej praktyce przygotowania do bierzmowania, np.: osobiste zgłoszenie się kandydata do bierzmowania, potwierdzone stosownym pismem; indywidualna rozmowa duszpasterska z kandydatem; nabożeństwa; spotkania. W niemieckich parafiach, w przeciwieństwie do polskich, wiele wysiłku i uwagi wkłada się w zaproszenie młodzieży do przyjęcia bierzmowania i wzięcia udziału w proponowanym przygotowaniu. Związane to jest z sytuacją, w której wielu młodych nie jest w bezpośrednim zasięgu oddziaływania duszpasterskiego parafii ze względu na ich dystans do wiary i Kościoła. Podkreśla się, by zaproszenie do młodych kierować osobiście, otwarcie i serdecznie, aby mogli oni w sposób dobrowolny je przyjąć. Najczęściej stosuje się osobiste i pisemne zaproszenie wszystkich osób z danej grupy wiekowej, ochrzczonych oczywiście w Kościele Rzymskokatolickim. Nieraz zaproszenie kieruje się też do rodziców. Wykorzystuje się także ogłoszenia parafii, kościelne biuletyny informacyjne, a nawet lokalną prasę. Świadczy to o dużym nakładzie sił i środków na początku przygotowania, zmierzających do zachęcenia młodzieży, która przez długi czas, nieraz od I Komunii świętej, nie miała kontaktu z parafią. W Polsce nie ma jeszcze takiej potrzeby, ponieważ dzięki nauczaniu religii w szkole, które prowadzą nie tylko świeccy katecheci, związani z parafią, ale również księża, informacja dociera do wszystkich uczniów. Przekazują ją sobie również sami uczniowie, którzy tworzą zespoły klasowe złożone w większości z katolików. Takich warunków nie ma w Niemczech. Niemniej warto jednak w polskiej rzeczywistości bardziej zainteresować się tymi, którzy nie pojawiają się w parafii na początku przygotowania oraz tymi, którzy z różnych przyczyn zrezygnowali z parafialnej katechezy do bierzmowania. Wydaje się, ze w polskim Kościele wciąż dominuje przekonanie, iż ludzie, w tym młodzież, sami przyjdą do parafii. Tymczasem coraz częściej trzeba ich dzisiaj szukać i wyjść do nich z zaproszeniem. W tym celu konieczna jest zmiana mentalności w polskim Kościele oraz permanentna formacja duchownych w duchu nowej ewangelizacji ${ }^{20}$. Wśród wielu elementów ramowego przebiegu przygotowania do bierzmowania szczególną uwagę warto zwrócić na spowiedź kandydatów. W Polsce stanowi ona istotny komponent całego procesu przygotowania, a przed samym bierzmowaniem wymagana jest do posiadania właściwej wewnętrznej dyspozycji do przyjęcia bierzmowania. Diametralnie różna jest pod tym względem sytuacja w Niemczech, gdzie kwestię spowiedzi traktuje się w dosyć dowolny, a nawet marginalny sposób. Kandydatom do bierzmowania proponuje się wprawdzie spowiedź, ale nie stanowi ona koniecznego obowiązku przed przyjęciem bierzmowania, zaś w trakcie przygotowania docenia się sakrament spowiedzi, ale w praktyce proponuje się tylko indywidualną rozmowę, która może, ale nie musi doprowadzić do spowiedzi. Przyczyną takiego stanu rzeczy może być

${ }^{20}$ Por. R. Kaczmarek, Model katechezy, dz. cyt., s. 487n. 
swoista interpretacja Kodeksu prawa kanonicznego, który mówi o konieczności właściwego dysponowania kandydata do godziwego przyjęcia bierzmowania (por. KPK 889 \$2), a mianowicie, że ocena dyspozycyjności należy do niego samego. On sam decyduje, czy chce przed bierzmowaniem przyjąć sakrament spowiedzi, czy nie ${ }^{21}$. Przy tym trzeba zwrócić uwagę na ogólny brak praktyki spowiedzi w niemieckim Kościele, co powoduje, że kandydaci do bierzmowania nie są z nią oswojeni, gdyż nie praktykowali jej od czasu I Komunii świętej, a w skrajnych przypadkach wcale nie mają doświadczenia spowiedzi. Trudno im jest więc podjąć decyzję o skorzystaniu z sakramentu pokuty i pojednania. Proponowane w niektórych materiałach służących w przygotowaniu do bierzmowania rozwiązania przybliżenia młodym i ukształtowania spowiedzi z polskiego punktu widzenia budzą pewne wątpliwości ${ }^{22}$. Kościół niemiecki może w tej kwestii wiele nauczyć się od Kościoła w Polsce, który dba o wychowanie dzieci i młodzieży do korzystania z sakramentu pokuty i pojednania, gdyż nie tylko odnawia on łaskę chrzcielnego oczyszczenia, ale jest istotnym środkiem pracy nad sobą i kształtowania sumienia.

\section{Dobrowolny czy zobowiązujący charakter uczestnictwa w katechezie do bierzmowania?}

Katecheza do sakramentu bierzmowania musi stawiać czoła wielu wyzwaniom, wśród których jest również problem uczestnictwa młodzieży w przygotowaniu: na ile stawiać na dobrowolność uczestnictwa, a na ile zobowiązywać do niego?

W Polsce w chwili podjęcia decyzji o rozpoczęciu przygotowania do bierzmowania kandydat jest zobowiązany do uczestnictwa w przewidzianych spotkaniach. Bardzo często jest to konsekwencja własnej prośby o włączenie go do grona kandydatów do bierzmowania, w której deklaruje zarazem wypełnianie przewidzianych zobowiązań $^{23}$. Pojawia się jednak pytanie, czy prośba ta jest szczera i wynika z osobistego przekonania kandydata, czy zostaje złożona na skutek tego, że taka jest „procedura” rozpoczęcia przygotowania w parafii. Od tego między innymi zależy w jakim stopniu młody człowiek będzie realizował przyjęte obowiązki. Również w Niemczech zgłoszenie się na piśmie kandydata do bierzmowania implikuje przyjęcie zobowiązania, ale jeszcze nie decyzję przyjęcia sakramentu ${ }^{24}$. Jednakże w trakcie przygotowania zarówno w Polsce, jak i w Niemczech zdarza się, że młodzież jest nieobecna na wyznaczonych w ramach przygotowania spo-

\footnotetext{
21 Por. Firmpastoral in der Diözese Rottenburg-Stuttgart, Rottenburg a. N. 2012, s. 32.

22 Zob. J. Ehebrecht-Zumsande, B. Kassens, Wie das perlt...! Firmvorbereitung mit den „Perlen des Glaubens“, München 2008, s. 169-173.

23 Por. Indeks oraz Katechizm. Przygotowanie do Sakramentu Bierzmowania, Płock 2006, s. 4.

24 Por. Erzdiözese Freiburg, Orientierungsrahmen zum Firmpastoral, dz. cyt., s. 10; Por. Orientierungsrahmen für Firmpastoral im Bistum Fulda, dz. cyt., s. 15.
} 
tkaniach lub przychodząc na nie, nie jest zainteresowana ich treścią. Ta druga sytuacja znacznie utrudnia prowadzenie spotkania, zwłaszcza wtedy, kiedy dana osoba swoim zachowaniem rozbija pracę grupy.

W Polsce w prawie wszystkich diecezjach przyjęła się praktyka indeksów do bierzmowania, w których potwierdzona zostaje obecność kandydata na przewidzianych spotkaniach. Z jednej strony jest to sposób, żeby mobilizować młodziė do uczestnictwa, a z drugiej strony indeksy pokazują, w jakim stopniu młodzież wywiązuje się z podjętych zobowiązań. W Niemczech zaś większość katechetów rezygnuje z wprowadzania potwierdzeń obecności na spotkaniach. Tylko niektórzy w sytuacji, gdy ktoś opuszcza przygotowanie do bierzmowania lub jest nim niezainteresowany, dopuszczają jako instrument regulacyjny: indeksy do bierzmowania, listy obecności, listy z podpisami uczestników, a także układ pomiędzy młodzieżą a katechetą, osobiste rozmowy z proboszczem lub etatowymi współpracownikami ${ }^{25}$. Można przypuszczać, że praktyka stosowania indeksów do bierzmowania w Polsce oraz niestosowanie ich w Niemczech (w większości przypadków), ma związek z mentalnością Polaków i Niemców. Niemcy z natury są obowiązkowi i jeżeli deklarują się w jakiejś sprawie, to sumiennie realizują przyjęte zobowiązania. Polacy zaś często luźno podchodzą do zobowiązań oraz funkcjonują na zasadzie kontroli. Jest to skutek historycznych procesów, związanych z brakiem wolności. Sprawa indeksów do bierzmowania wzbudza wiele kontrowersji. Często sami odpowiedzialni za przygotowanie do bierzmowania twierdzą, że ta forma nie jest dobrym sposobem wprowadzania młodzieży w świat liturgii i praktyk religijnych, choć niekiedy okazuje się najprostsza i konieczna. Również ze strony kandydatów i rodziców docierają czasami głosy negatywne, krytykujące rozbudowane formy indeksów kandydatów, w których należy potwierdzać udział w każdej niedzielnej Mszy Świętej, comiesięcznej spowiedzi i innych nabożeństwach. Indeksy są albo elementem modelu w danej diecezji, albo należą do modeli parafialnych i nie są uwzględniane w rozporządzeniach diecezjalnych, zaś duszpasterze wskazują na konieczność pewnej formy egzekwowania praktyk religijnych. Ks. P. Mąkosa, dokonując bilansu zysków i strat praktyki stosowania indeksów, dochodzi do wniosku, że niosą one ze sobą zdecydowanie więcej problemów niż korzyści. Wśród pozytywnych stron ich stosowania zauważa, że stanowią one dużą motywację dla młodzieży i wpływają na zwiększenie frekwencji w różnego rodzaju spotkaniach. Ich negatywne oddziaływanie polega na tym, że uczą formalnego podejścia do wiary, sakramentów i moralności, czego skutkiem jest najczęściej rytualizm liturgicznym i moralizm. Ostatecznie jedynie tymczasowo zwiększa się udział młodzieży w praktykach religijnych, a po ustaniu obowiązku rezygnuje ona

${ }_{25}$ Por. Umfrage zur Firmpraxis in der Diözese Speyer 2006, [w:] Für die Seelsorge. Pastoralbeilage zum Oberhirtlichen Verordnungsblatt für das Bistum Speyer. Dokumentation Firmkatechetischer Kongress für die Diözese Speyer, 1 (2007), s. 35. 
z udziału w życiu liturgicznym ${ }^{26}$. Dołączając się do tych opinii, proponowałbym rozważenie kwestii indeksów z innej strony. Być może problem nie leży w praktyce stosowania indeksu, ale w sposobie korzystania z niego tak przez kandydatów, jak i prowadzących. Najważniejsze, aby podchodzić do tej formy egzekwowania rozsądnie i w wyważony sposób oraz sensownie wytłumaczyć rodzicom i kandydatom cel potwierdzania obecności. Indeks ma być bardziej informacją dla kandydata i rodziców, dzięki której mogą obserwować rozwój duchowy oraz zaangażowanie młodego człowieka w przygotowanie do bierzmowania, niż kontrolą obecności. Można go potraktować jako rodzaj książeczki do mierzenia „ciśnienia wiary”, dzięki której możemy powiedzieć wiele o kondycji kandydata i wskazać mu na co w zakresie życia duchowego ma zwrócić większą uwagę. Indeks nie może stać się bezwzględnym i zimnym wyznacznikiem, czy dopuścić kogoś do bierzmowania, czy nie. Wpis w indeksie musi być uzupełniony rozmową z kandydatem na temat jego drogi wiary, jej przeżywania i ewentualnych trudności z nią związanych, tak by stworzyć atmosferę wolnego wyboru i troski o młodego człowieka. Konieczne jest również właściwe podejście do zbierania podpisów (mogliby je dawać nie tylko duszpasterze, ale również rodzice, albo sam kandydat, jeśli np. zapomniał indeksu lub było utrudnione podejście do kapłana). Byłby to znak zaufania do kandydatów i ich rodziców. Pozytywną stroną indeksów, przy właściwym do nich podejściu przez duszpasterzy, jest to, że podpisywanie indeksu może stać się okazją do krótkiej rozmowy, zainteresowania kandydatem, zachęcenia go do zaangażowania itp. Ta możliwość bezpośredniego kontaktu pozwala budować więzi pomiędzy młodymi ludźmi a duszpasterzem lub katechetą ${ }^{27}$.

\section{Rodzaje i formy spotkań katechetycznych w parafii}

Istotnym elementem modelu katechezy przygotowującej do bierzmowania są rodzaje i formy spotkań katechetycznych w parafii. Dyrektorium katechetyczne Kościoła katolickiego $w$ Polsce stanowi, że należą do nich przede wszystkim spotkania zbiorowe kandydatów, celebracje oraz spotkania w małych grupach (por. PDK 107). To samo powtarza Podstawa programowa katechezy Kościoła katolickiego $w$ Polsce (por. PPK, s. 69) oraz Program nauczania religii rzymskokatolickiej w przedszkolach i szkołach (por. PNR, s. 137). Zalecenia te realizowane są zasadniczo we wszystkich polskich diecezjach, choć należy dążyć, aby spotkania w grupach stały się praktyką wszystkich parafii. Zdarza się, że kandydaci biorą udział w dniach skupienia i wyjazdach rekolekcyjno-wypoczynkowych. Kościół niemiecki również proponuje młodzieży wyżej wymienione formy spotkań, ale

\footnotetext{
26 Por. P. Mąkosa, Katecheza młodzieży gimnazjalnej w Polsce. Stan aktualny i perspektywy rozwoju, Lublin 2009, s. 369n.

27 Por. R. Kaczmarek, Model katechezy, dz. cyt., s. 489n.
} 
są inaczej zorganizowane. Niemiecka praktyka wyróżnia się tym, że uwzględnia trudności w uzgodnienia w ciągu tygodnia regularnych terminów spotkań w grupach $\mathrm{z}$ młodzieżą z różnych rodzajów szkół i klas ${ }^{28}$. Z reguły można wyróżnić dwie zasadnicze koncepcje:

- wielomiesięczny proces katechetyczny, w ramach którego proponowane jest raz w tygodniu jedno spotkanie w małych grupach, trwające od jednej do dwóch godzin;

- kilka dni katechetycznych, w czasie których odbywają się całodniowe lub półdniowe zajęcia (zazwyczaj w soboty), podczas których pracuje się w stałych lub zmieniających się małych grupach.

Te obowiązkowe spotkania zostają uzupełnione zazwyczaj przez propozycje do wyboru: wycieczki, określane często jako „praktyka”, podczas której odwiedza się różne kościelne miejsca, instytucje i grupy, rozmowy z etatowymi współpracownikami duszpasterskimi lub przedstawicielami różnych gremiów. Można skorzystać również z mniejszych „eventów”, jak np. udział w ponadparafialnej pielgrzymce, czy spotkaniu młodzieżowym. W ostatnim czasie dochodzą to tego coraz częstsze koncepcje, zakładające, że kandydaci przygotowują się do bierzmowania podczas krótkiego, ale intensywnego procesu. Sprawiają one wrażenie krótkoterminowych „crash kursów”, ale kiedy się im dokładniej przyjrzymy, to zauważymy, że wspólne przeżycia stają się punktem wyjścia dla procesu nauczania ${ }^{29}$. Wśród nowych koncepcji spotyka się wspólną pielgrzymkę rowerową lub pieszą. Podjęto ją np. w obszarze duszpasterskim Frechen pod hasłem „Matthias wild side”. Droga prowadziła szlakiem św. Jakuba, a częściowo szlakiem św. Mateusza, a jej celem był grób Apostoła Mateusza w Tier ${ }^{30}$. Ks. Christof May zapronował z kolei rowerowy kurs do bierzmowania jako alternatywę do cotygodniowych spotkań katechetycznych, aby wzmocnić w młodych poczucie wspólnoty i sens chrześcijańskiej Communio. Podczas siedmiodniowej pielgrzymki pokonał $\mathrm{z}$ kandydatami do bierzmowania ze swojej parafii 350 kilometrów z Wiesbaden do klasztoru w Münsterschwarzach. Tematyka dotyczyła historii stworzenia, ukazując człowieka jako stworzenie na obraz i podobieństwo Boga. Każdego dnia nawiązywano również do jednego z sakramentów ${ }^{31}$.

Inną ciekawą propozycją jest „wspólny tydzień życia”, podczas którego kandydaci do bierzmowania wraz ze swoimi katechetami nocują w pomieszczeniach parafialnych i wspólnie spędzają czas wolny. Wszyscy spotykają się w niedzielę

\footnotetext{
28 Por. Umfrage zur Firmpastoral im Bistum Limburg 2007/8. Dokumentation der Ergebnisse, Limburg 2008, s. 9.

29 Por. P. C. Hörnig, Firmkonzepte heute, w: Gott entdecken - Gott bezeugen. Firmkatechese heute, P. C. Hörnig (Hg.), Freiburg im Bresigau 2014, s. 121 .

30 Zob. R. Hundenborn, Firmvorbereitung als Pilgerweg, [w:] Gott entdecken - Gott bezeugen, dz. cyt., s. 177-180.

31 Zob. Ch. May, Mit dem Rad Glauben erfahren. Firmradkurs, Berlin 2006.
} 
wieczorem i są ze sobą cały tydzień, w ciągu dnia wypełniając swoje codzienne obowiązki, a popołudniami i wieczorami uczestnicząc w katechezach, modlitwach, spotkaniach i różnych formach rozrywki. Tam, gdzie zastosowano tę koncepcję zauważono: wyraźną dynamikę grupy oraz intensywne rozmowy uczestników pomiędzy sobą i z prowadzącymi. Jest to efekt większego zaufania, bycia razem w codziennych sytuacjach i doświadczenia, że „Kościół może być cool”32.

Wśród form przygotowania do bierzmowania w Niemczech o wiele bardziej istotną rolę niż w Polsce odgrywa praktyka socjalna lub diakonijna w jednej z charytatywnych instytucji kościelnych. Jeden z niemieckich podręczników do bierzmowania proponuje 12 praktycznych przykładów, jak można zaangażować młodzież: dom starców, szpital finansowany z katolickich źródeł, dzień akcji dla dzieci w centrum społecznym, kobieca kawiarenka (akcja zbierania ubrań dla dzieci), akcja zbierania produktów do koszyka na zakupy, przechodni dom dla bezdomnych, tzw. „Neustadter Tafel“ (zbieranie artykułów żywnościowych i rozdzielanie ich potem $\mathrm{w}$ dwóch dniach tygodnia ludziom potrzebującym), pomoc dzieciom azylantów w odrabianiu zadań, odwiedzanie chorych w parafii, pomoc w dziennych instytucjach dla dzieci, projekt dla nowych osób, które wprowadziły się do miejscowości, analiza socjalna parafii ${ }^{33}$. Taka forma katechezy jest ważnym krokiem na drodze osobistego rozwoju młodzieży poprzez uczenie wrażliwości na drugiego człowieka, który potrzebuje naszej pomocy. Młodzi uświadamiają sobie, że żywa wiara realizuje się poprzez konkretne uczynki miłości w duchu wyobraźni miłosierdzia, o którą apelował św. Jan Paweł II. Warto takie formy coraz bardziej upowszechniać jako elementy „diakonagogicznej” katechezy ${ }^{34}$ do bierzmowania również w Polsce.

Wśród innych, godnych zauważenia, form przygotowania jest wspólne przygotowanie świadków i kandydatów do bierzmowania. Zostało ono przeprowadzone jako eksperyment m.in. w kolońskiej parafii św. papieża Jana XXIII. Warunkiem był wybór świadka bierzmowania na początku przygotowania. Każdy z nich otrzymał pismo powitalne, w którym została wyjaśniona ich przyszła rola oraz zaproszenie na wspólne spotkanie „startowe”. W jego ramach odprawiono Msza świętą posłania, podczas której parafia wzięła na siebie patronat modlitewny nad całym procesem przygotowania. $\mathrm{W}$ dalszej części przygotowania miały miejsce do wyboru: tzw. „4 Spirits” (cztery Msze młodzieżowe na obszarze miasta Kolonia) lub udział w zamiejscowych rekolekcjach do bierzmowania. Koncepcja uzupełniona została udziałem świadka i kandydata do bierzmowania w trzech podstawowych

\footnotetext{
32 Por. W. Obermann, Lebenswoche, [w:] Gott entdecken - Gott bezeugen, dz. cyt., s. 182n.

${ }_{33}$ Por. Ch. Arendt-Stein, T. Kiefer, Firmvorbereitung mit Herz. Sozialpraktika im Rahmen der Firmkatechese, München 2006, s. 11.

${ }^{34}$ Autorami tego pojęcia są Johanes Stücker-Brüning i Ernst Werner, którzy nawiązując do pojęcia mistagogii Karla Rahnera. Zob. J. Stücker-Brüning, E. Werner, Katechese und Diakonie: ein ungeklärtes Verhältnis?, Katechetische Blätter 2 (2001), s. 149.
} 
modułach realizacji chrześcijańskiego życia: spotkanie z szafarzem bierzmowania, kierowniczką noclegowni dla potrzebujących i duszpasterzem więzienia. Wielu świadków było wdzięcznych za taką propozycję przygotowania do bierzmowania ${ }^{35}$.

W niemieckich diecezjach o wiele bardziej rozpowszechnioną formą spotkań są wyjazdy rekolekcyjno-wypoczynkowe, zdarzają się również dni skupienia lub typowe rekolekcje dla kandydatów do bierzmowania ${ }^{36}$. Warto przenosić te doświadczenia na polski grunt, gdyż wspólne wyjazdy młodych sprzyjają lepszemu poznaniu się tak młodzieży między sobą, jak i prowadzących z kandydatami. Nawiązane wtedy relacje stanowią bardzo dobry fundament dalszego przygotowania do bierzmowania w parafii. Ponadto wyjazdy takie sprzyjają doświadczeniom duchowym, których brakuje w domach młodzieży, a nawet nie można ich w takim stopniu zapewnić w parafii. Przebywanie ze sobą młodych ludzi stwarza im możliwość życia przez pewien czas jako „mały Kościół”.

Godna zauważenia jest również praktyka przygotowania do bierzmowania w grupach, do których przyporządkowuje się młodzież według płci ze względu na przeżywany okres adolescencji ${ }^{37}$.

W Niemczech proponowane formy spotkań są ściśle związane z celami, które zostały przyporządkowane przygotowaniu do bierzmowania w danej diecezji, społecznymi lub lokalnymi uwarunkowaniami oraz czasowymi możliwościami adresatów.

Tak w Polsce, jak i w Niemczech młodzieży proponuje się również różne spotkania liturgiczne. W Polsce są one związane przede wszystkim z Eucharystią, nabożeństwami okresowymi i celebracjami dostosowanymi do programu przygotowania. Przed samym bierzmowaniem w wielu diecezjach pojawia się propozycja udziału kandydatów w nowennie do Ducha Świętego czy Triduum przed bierzmowaniem. W przeciwieństwie do tych tradycyjnych form liturgicznych, w Niemczech praktykuje się bardziej niekonwencjonalne: noc czytania Pisma Świętego, tzw. Frühschicht i Spätschicht (ranna i późna zmiana), medytacje, modlitwy Taize, dzień lub noc pojednania, nabożeństwo na zakończenie nocnej wędrówki, nabożeństwa na łonie natury, itp. Istnieją również bardziej tradycyjne formy: adoracje, młodzieżowe drogi krzyżowe, nabożeństwa pokutne. Często jednak udziału w niedzielnej Eucharystii nie uważa się za najważniejszą formę w przygotowaniu do bierzmowania. Wiąże się to nie tylko $\mathrm{z}$ formułowanymi celami

35 Por. T. Döker, Gemeinsame Vorbereitung von Paten und Firmlingen, w: Gott entdecken - Gott bezeugen, dz. cyt., s. 188.

36 Szczególne doświadczenia w tym względzie ma archidiecezja Köln. Wydział Duszpasterstwa Młodzieży proponuje młodym ludziom przeżycie rekolekcji, stanowiących szczególny Tydzień Wiary w ostatnim tygodniu roku liturgicznego przed uroczystością Chrystusa Króla. Odbywają się one pod hasłem: TIME OUT - AusZeit. Ich treścią są rozważania Psalmów. Zob. M. Bauer, Time out, AusZeit. Jugendexerzitien 2011. Heute, hört auf seine Stimme (Ps 95,7), Köln 2011.

37 Por. C. Hofrichter, Mädchen brauchen Frauen, Jungen brauchen Männer, w: Firmvorbereitung mit Esprit. Grundlagen, C. Hofrichter, B. Strifler (Hg.), Stuttgart 2001, s. 76-86. 
przygotowania do bierzmowania, ale również z wyobcowaniem młodzieży z rzeczywistości religijnej oraz wynikającym z tego przekonaniem, że młodzież trzeba wprowadzać w świat liturgii małymi krokami. Wspólne świętowanie Eucharystii ma być zwieńczeniem tej drogi. Kościół niemiecki może skorzystać zaś z polskich doświadczeń związanych z Triduum lub Nowenną przed przyjęciem sakramentu bierzmowania $^{38}$. Kościół w Polsce może zaś uczyć się od Kościoła niemieckiego stosowania nowych form liturgicznych, które spotkałyby się z zainteresowaniem oraz chęcią zaangażowania ze strony młodych ludzi. Należy dołożyć wszelkich starań, aby kandydatów do bierzmowania włączyć jak najlepiej w tradycyjną liturgię, jeśli są już na niej obecni, tak aby poczuli się potrzebni. Jeśli pozostawimy ich na początku w roli widzów, trudno im będzie uczynić z liturgii własne przeżycie ${ }^{39}$.

Zarówno w Polsce, jak i w Niemczech spotykamy różne formy spotkań ponadparafialnych, na które są zapraszani kandydaci do bierzmowania. Część spotkań jest przeznaczona tylko dla nich, a część stanowi propozycję dla ogółu młodzieży. Są one bardzo zróżnicowane oraz mają możliwość poruszyć ich zarówno poprzez formę, jak i język przekazu. Młodzi doświadczają tego, że na drodze wiary nie są sami, ale idą nią także rówieśnicy. Spotkania dla samych tylko kandydatów nie są zbyt powszechne w polskich diecezjach. W kilku proponuje się im uczestnictwo w pielgrzymce (archidiecezja częstochowska: do katedry na początku przygotowania i po bierzmowaniu; diecezja sosnowiecka: dziękczynna za przyjęcie sakramentu bierzmowania do Kalwarii Zebrzydowskiej; diecezja tarnowska: dziękczynna dla bierzmowanych z klas III diecezji tarnowskiej w drugą sobotę czerwca; zamojsko-lubaczowska: pielgrzymka bierzmowanych w maju każdego roku). Pozostałe propozycje mają charakter ogólnodiecezjalnych spotkań młodzieży, w których uczestniczą również kandydaci do bierzmowania. Najczęściej młodzież jest zachęcana do udziału w Światowych Dniach Młodzieży, które organizuje się w katedrach w Niedzielę Palmową. W niektórych diecezjach organizowany jest diecezjalny dzień młodzieży. Często jako miejsce spotkań wybiera się sanktuarium lub inne miejsce o szczególnym znaczeniu dla diecezji, np.: spotkanie młodych na Górze św. Anny w diecezji opolskiej, diecezjalne spotkanie młodzieży w Skrzatuszu w diecezji koszalińsko-kołobrzeskiej, wakacyjne spotkanie młodych w Krzeszowie lub Legnickim Polu w diecezji legnickiej, w sanktuarium maryjnym w Licheniu w diecezji włocławskiej, w Ośrodku Archidiecezjalnym „Rybaki” w diecezji warmińskiej. Spotkania młodych mają w niektórych diecezjach wyjątkową formę. W archidiecezji gnieźnieńskiej co roku trwają tzw. „Dni Radości”, będące swoistymi

\footnotetext{
38 Por. R. Kaczmarek, Model katechezy, dz. cyt., s. 491.

39 Ks. bp Franz Vorrath z diecezji Essen stawia pytanie: „czy w parafiach Msza niedzielna jest tak sprawowana, by bierzmowana młodzież znalazła w niej swoje miejsce?”. Stwierdza zarazem: „celem naszego zaangażowania w przygotowanie do bierzmowania jest również to, aby młodym chrześcijanom pokazać parafię jako życiową przestrzeń dla ich wiary”. Por. List bpa Franza Vorratha w sprawie bierzmowania, Anamnesis 3 (2003), s. 23.
} 
dniami skupienia lub weekendowymi rekolekcjami dla młodzieży, których program oparty jest na rytmie dnia znanym z Taizé czy Europejskich Spotkań Młodych. Podobne spotkania - w duchu Taizé oraz Ekumeniczna Modlitwa Młodych organizowane są dla młodzieży w diecezji opolskiej. Z kolei w diecezji siedleckiej warto zwrócić uwagę na „Jerycho Młodych” odbywające się w Sanktuarium Błogosławionych Męczenników Podlaskich w Pratulinie. Stanowi ono kontynuację idei i ducha Światowych Dni Młodzieży przeżywanych w Niedzielę Palmową. W diecezji świdnickiej ma miejsce coroczne spotkanie młodych „Owczarnia”, na które składa się Eucharystia, adoracja Najświętszego Sakramentu, świadectwo oraz koncert zespołu chrześcijańskiego. Jeszcze inną formę ma spotkanie dla młodych „Exodus Młodych”, organizowane w diecezji zamojsko-lubaczowskiej. W diecezji łomżyńskiej odbywa się Festiwal Młodych w Płonce Kościelnej, organizowany przez Katolickie Stowarzyszenie Młodzieży Diecezji Łomżyńskiej ${ }^{40}$. Wymienione tu spotkania mają wspólne elementy, m.in.: Eucharystię, adorację Najświętszego Sakramentu, spotkania w grupach, świadectwa, koncerty.

O wiele częściej ze spotkań ponadparafialnych korzysta się w Niemczech. Wynika to $\mathrm{z}$ istniejącej tam sytuacji pastoralnej - funkcjonowania Kościoła Rzymskokatolickiego w sytuacji diaspory (zwłaszcza w Niemczech Wschodnich) oraz łączenia parafii w duże jednostki duszpasterskie, co wymaga zacieśnienia współpracy w przygotowaniu do bierzmowania pomiędzy kilkoma parafiami ${ }^{41}$. Zachęca się również młodzież do zaangażowania na płaszczyźnie dekanalnej, co poszerza podstawowe propozycje ${ }^{42}$. Wśród nich są: nieszpory młodzieżowe w jednym z klasztorów, wyjazdy do Taize, Asyżu lub innych miejsc duchowości chrześcijańskiej oraz weekendy w domach młodzieżowych, gdzie często młodzież uczestniczy w różnych kursach. W kilku diecezjach w dekanatach odbywają się dni kandydatów do bierzmowania. Nie brakuje również spotkań młodzieży w obrębie diecezji: w dwóch diecezjach odbywa się dzień bierzmowanych, który ma miejsce po uroczystości udzielenia sakramentu bierzmowania, a w diecezji Essen w katedrze organizuje się „Noc kandydatów do bierzmowania”. Niektóre wydarzenia są ściśle związane z konkretną diecezją ${ }^{43}$.

Interesującą propozycją w niektórych niemieckich diecezjach jest zachęta do współudziału kandydatów do bierzmowania w Mszy Świętej Krzyżma Świętego.

\footnotetext{
40 Takie formy spotkań zostały wymienione w ankietach poszczególnych diecezji.

${ }^{41}$ Por. Umfrage zur Firmpastoral im Bistum Limburg 2007/8. Dokumentation der Ergebnisse, Limburg 2008, s. 9. Przykładem tego są wyjazdy kandydatów do bierzmowania sąsiadujących ze sobą parafii w diecezji Görlitz.

${ }_{42}$ Por. Orientierungsrahmen für Firmpastoral im Bistum Fulda, N. Bug (Red.), Referat Gemeindekatechese, Seelsorgeamt im Bistum Fulda (Hg.), Fulda 2010, s. 14; Erzdiözese Freiburg, Orientierungsrahmen zum Firmpastoral im Jugendalter in der Erzdiözese Freiburg, Freiburg 2007, s. 10.

${ }^{43}$ W diecezji Trier uczestniczą w dniach „Heilig Rock”. „Heilige Rock“ to relikwia przechowywana w katedrze w Trier, będąca fragmentem tuniki Jezusa. Co roku odbywa się tam pielgrzymka. Zob. http://www.heilig-rock-wallfahrt.de/start.html. Por. R. Kaczmarek, Model katechezy, dz. cyt., s. 383n.
} 
W Polsce można by skorzystać z tej inspiracji, gdyż młodzież lepiej będzie przeżywać samo namaszczenie Krzyżmem Świętym, którego poświęcenia była świadkiem. Uwidoczni się jeszcze bardziej związek bierzmowania z posługą biskupa, szczególnie w sytuacji, kiedy biskup nie może przybyć do parafii i bierzmowanie jest udzielane przez delegowanego kapłana. Kolejną inspiracją dla nas są praktykowane nieraz w Niemczech spotkania kandydatów z szafarzem bierzmowania. Młodzież przybywa do siedziby biskupa lub biskupa pomocniczego, który później będzie im udzielał sakramentu. Dzięki temu młodzi poznają wcześniej szafarza bierzmowania i mają możliwość rozmowy z nim, dzięki czemu przestaje on być kimś obcym dla nich podczas samej uroczystości. Wizyta u biskupa często związana jest z odwiedzinami katedry.

Trzeba zauważyć, że wśród niemieckich propozycji nie ma spotkania w ramach Światowych Dni Młodzieży w katedrze, co w polskim modelu stanowi bardzo często formę udziału kandydatów do bierzmowania. Najpierw osoby odpowiedzialne za przygotowanie w parafii muszą wyzwolić się od negatywnego spojrzenia na masowe spotkania młodzieży i zrozumieć potrzebę spotkań w większej grupie na płaszczyźnie ogólnodiecezjalnej. Takie szerokie spojrzenie otworzy drogę do przeżycia przez młodych ludzi Kościoła - w wymiarze lokalnym i powszechnym, a nie tylko parafialnym.

\section{Jak informować młodzież?}

Istotną kwestią w procesie przygotowania do bierzmowania jest również sposób docierania $\mathrm{z}$ informacją oraz komunikowania się z młodzieżą. Wyniki ankiet pokazują, że w polskiej rzeczywistości najbardziej rozpowszechnione są ogłoszenia parafialne w kościele oraz biuletyny informacyjne parafii, następnie szkolna katecheza i spotkania z kandydatami. Na kolejnej pozycji wykorzystuje się możliwość informowania poprzez sms-y oraz portale społecznościowe, komunikatory i strony internetowe dla kandydatów do bierzmowania lub strony internetowe parafii. Porównując to z wynikami ankiet diecezji niemieckich wynika, że kolejność korzystania z wyżej wymienionych sposobów komunikacji jest tam odwrotna. Najczęściej używa się nowoczesnych mediów: portali społecznościowych, stron internetowych, komunikatorów, forów internetowych. Następnie dużą rolę odgrywa komunikacja za pomocą smsów oraz docieranie do kandydatów za pośrednictwem listu. Dopiero na końcu znalazły się ogłoszenia w gazetach, w ramach nabożeństw czy szkolnego nauczania religii. Wynika to z tego, że w Niemczech większość młodych jest obecnych w sieci, rzadko zaś w świątyni ${ }^{44}$. Podobna sytuacja obserwowana jest również w Polsce. Skoro młodzi żyją w społeczeństwie informatycznym i wirtualnej

${ }^{44}$ Por. R. Kaczmarek, Model katechezy, dz. cyt., s. 490-493. 
rzeczywistości, należy w większej mierze wykorzystywać w Polsce nowe sposoby komunikacji, szczególnie Facebooka i smsy, gdyż smartfon stał się nieodłącznym towarzyszem młodego człowieka, z którym nie rozstaje się ani na chwilę. Sensowne jest również tworzenie różnych aplikacji, z których mogliby korzystać kandydaci. Nie bez znaczenia pozostają również tradycyjne, ale osobiście kierowane do młodych ludzi zaproszenia i informacje. Doświadczenie uczy, że nieocenioną formą komunikowania młodzieży jest przekazywanie sobie przez nich samych informacji, wzajemne przypominanie sobie i zachęcanie się do uczestnictwa w spotkaniach. Warunkiem jest jednak dobra atmosfera tych spotkań oraz stworzenie $z$ danej grupy kandydatów zgranego zespołu.

Katecheza przygotowująca do bierzmowania powinna nieustannie się odnawiać. Wynika to z niespotykanego dotychczas tempa zmian cywilizacyjnych, którym podlegają młodzi ludzie. Tym bardziej potrzebują oni umocnienia, jakie przynosi ze sobą sakrament bierzmowania. Stanowi on niezwykłą szansę w procesie wiary młodego człowieka. Nie można jej zmarnować, bo szybko się nie powtórzy. Dlatego poszukiwanie optymalnego modelu katechezy do bierzmowania, a szerzej duszpasterstwa młodzieży, jest wyrazem troski o młodego człowieka, który został nam dany i zadany w czasie przygotowania do bierzmowania. Korzystanie ze wzajemnych doświadczeń i uczenie się od siebie nawzajem może przynieść nowe i cenne inspiracje. Widać to na przykładzie porównanych elementów organizacyjnych katechezy przygotowującej do bierzmowania w Polsce i w Niemczech. Bez ich właściwego ukształtowania najlepiej dobrana treść i metody przekazu nie będą mogły przynieść pełnych owoców. Trzeba nieraz zaryzykować pójście nową drogą, bo tkwiąc na tradycyjnych tylko pozycjach, możemy rozminąć się z tymi, których chcemy objąć katechetyczną troską, wskazując im niezmienne wartości.

\section{ORGANIZATIONAL ELEMENTS OF THE RELIGIOUS EDUCATION WHICH PREPARES YOUNG PEOPLE FOR THE SACRAMENT OF CONFIRMATION IN POLAND AND GERMANY}

\section{Summary}

The religious education which prepares for Confirmation should be incessantly renewed. It results from the unprecedented pace of civilizational changes, on which the youth are exposed. They need reinforcement which the Sacrament of Confirmation brings. It also constitutes the unusual chance in the process of faith of the young man. Seeking the optimal model of the religious education for Confirmation, and more widely a youth chaplaincy, is an expression of care of the young man. Using mutual experience and learning from each 
other can bring new and valuable inspiration. One can see it on the example of compared organizational elements of the religious education which prepares for Confirmation in Poland and in Germany. Without their proper forming even the best selected content and methods of the transmission will not be able to bring full fruits.

Keywords: preparation for Confirmation, sacramental catechesis, catechesis of young people, parish catechesis 